\title{
EMPLOYMENT OF THE RESEARCH ENGINEERING SIMULATOR FOR PROJECT AND OPTIMIZING HUMANE - MACHINE INTERFACE (HMI)
}

\section{ZASTOSOWANIE SYMULATORA BADAWCZO- KONSTRUKCYJNEGO W PROCESIE PROJEKTOWANIA I OPTYMALIZACJI INTERFEJSU CZLOWIEK - MASZYNA}

\author{
Krzysztof Butlewski ${ }^{1}$, Dariusz Karczmarz ${ }^{2}$, Roman Marchwicki ${ }^{3}$, \\ Przemysław Mądrzycki ${ }^{4}$, Wojciech Puchalski ${ }^{5}$, Cezary Szczepański ${ }^{6}$ \\ (1 - 5) Air Institute of Technology \\ Instytut Techniczny Wojsk Lotniczych, 01-494 Warszawa, ul. Księcia Bolesława 6
}

(6) Telecommunication Research Institute

Przemysłowy Instytut Telekomunikacji, 00-991 Warszawa, ul. Poligonowa 30

e-mails: (1) krzysztof.butlewski@itwl.pl,(2)dariusz.karczmarz@itwl.pl,

(3)roman.marchwicki@itwl.pl, (4) przemyslaw.madzrycki@itwl.pl,

(5)wojciech.puchalski@itwl.pl, (6) cezary.szczepanski@pit.edu.pl

\begin{abstract}
In the process of optimizing of the human-machine interface (HMI) for military aircraft, the research-engineering simulator makes the basic testing instrument for the verification of the quality of the process. This paper describes the hardware architecture and the concept of the system of the computer-based engineering simulator. It presents some analyses of software and hardware solutions of the selected test benches of the simulator.
\end{abstract}

Keywords: research-engineering simulator, optimizing, aircraft operators

Streszczenie: W procesie optymalizacji interfejsu człowiek - maszyna dla wojskowych statków powietrznych, symulator badawczo-konstrukcyjny jest podstawowym narzędziem badawczym do weryfikacji jakości tego procesu. W artykule omówiono strukturę oraz koncepcję systemu komputerowego symulatora. Przedstawiono fragmenty analizy dotyczącej rozwiązań informatycznych oraz konstrukcyjnych wybranych stanowisk badawczych wchodzących w jego skład.

Slowa kluczowe: symulator badawczo-konstrukcyjny, optymalizacja, operatorzy wojskowych statków powietrznych 


\section{EMPLOYMENT OF THE RESEARCH ENGINEERING SIMULATOR FOR PROJECT AND OPTIMIZING HUMANE - MACHINE INTERFACE (HMI)}

\section{Preface}

In the process of optimizing of the human-machine interface (HMI) for military aircraft, the research engineeringsimulator makes the basic testing instrument for the verification of the quality of the process. The task of verification of the correctness of the implemented design solutions for the interface belongs to the group of ergonomic tests. In case of the referred simulator, the tests will include the range of measurements of psychophysiological parameters of aircraft's operators who use the proposed solutions while performing the test tasks. For this reason the simulator must enable efficient testing, recording and analyzing of the obtained results.

The assignments and functions of the research engineeringsimulator determine in a significant way the architectural solutions and environmental conditions, in which the simulator can operate properly and ensure credibility of the test results. Therefore, the analysis of architectural solutions should be conducted in strict connection with the functions and assignments performed by the simulator [1]. By such formulation of the problem, the test benches should be isolated and the assignments should be determined. The simulator [2] consists of software [3] and three test benches:

- the subject's test bench,

- the instructor's test bench,

- data analysis test bench.

\section{Organization and equipment of the test benches}

\subsection{Organization and equipment of the subject's test bench}

Ensuring the proper conduct of the test requires that the subject performs the tasks assigned by the instructor correctly, and the tasks result from the aim presented during the briefing. The subject's test bench will be the 
fundamental element of the performed tests. The bench equipment includes the following elements:

○ Data display system of aircraft's position in space, its flight characteristics and on-board equipment (cockpit of the simulated aircraft). Data is entered from the instructor's test bench computer, composed of touch screen monitors, panels with switches simulating bistable processes (switched on - switched off or mode selection) and the frame for firm fixing these elements on the simulator's cockpit.

- Flight control instruments for aircraft's spatial navigation.

Flight control instruments of the military aircraft's test simulator should replicate in a realistic way the actual technical solutions, employed on the modern aircraft, and above all the aircraft's functions. The search for resolving of the problem can follow in two directions. The first one is the adaptation of the cockpit of the certain military aircraft with all flight control instruments and flight instrument board. This solution provides high realism of mapping the pilot's direct environment. That makes the only advantage of this solution. The disadvantages include primarily limited upgrading capability of the research engineeringsimulator's cockpit, which is expected to enable HMI optimization for different kind of aircraft. Alternative direction employs ready-to-use devices imitating flight control instruments of the aircraft. The market offers a variety of such devices, but the decision on selecting the particular model depends on the availability of the supporting software and its susceptibility to modifications, in order to operate properly in the simulator. Initially, the following manipulators were selected for testing the model simulator:

- fingerstick, replicating the F-16 aircraft sidestick;

- throttle;

- pedals.

- Pilot chair and frame for fixing the flight control instruments and the presentation bench equipment;

The directions for resolving the problem are analogical with those for the flight control instruments. Employment of a typical pilot chair from a certain type of aircraft determinates respective technical and organizational cockpit solutions and generates additional cost. The simulator, in its fundamental design assumption, should be a universal device, susceptible to modification of the equipment and functional organization of cockpit. As for an initial solution, it was decided to use a universal chair with regulation 
of back-rest, arm-rest and foot-rest platform for pedals (see Fig.4). Employment of this chair will provide matching of individual operational position for the subject. Moreover, the frame's architecture, to which the chair is fixed, enables adding extra supports and shelves, which provide high reconfigurability of the test environment.

- Environment visualization system;

Environment visualization system consists of two basic elements: image generator and image presentation system [4].

In the last stage of design concept, the presentation system of plasma screens was selected, which provides high quality of image. The analysis of technical solutions shows that it is possible to employ professional frameless plasma monitors or standard panoramic plasma monitors with plastic frame, which make discontinuity in generated image. In both cases 60 -inch monitors were employed. Selection of the solution will depend on purchase and exploitation cost analysis in reference to the offered image display parameters. The plasma monitors are installed on special supports, which enable constructing display walls of different shapes.

\subsection{Organization and equipment of the instructor's test bench}

The instructor's test bench should provide the following functions:

- starting and stopping the simulator, as well as providing continuous monitoring of its operation;

- modification of the assumptions of a simulated task;

- recording required information on the test;

- capability of monitoring the subject's cockpit performance;

- development of new test scenarios;

- modification of visualization system data base;

- communication with the subject's test bench.

Analysis of the above simulator's functions enables determination of its organization and the localization in the laboratory, as well as technical equipment, including:

- Internal communication system between the instructor's bench and the subject's bench;

○ Instructor's computer bench;

The fundamental functions of preparing and running the test process will be made on a computer.

\subsection{Psycho-physiological parameters recording system}


For this analysis, this is the essential element of the simulator's equipment. As the sensors are attached to the subject's body and some elements are placed close to the chair, they can be considered as part of the subject's bench. In fact, the system is highly autonomous.

As medical equipment for measuring and recording of certain psychophysiological parameters makes the basic equipment of the system, the elements of the system should be placed close to the subject's bench, in order to avoid long cables attached to the measurement probes and sensors on the subject's body, as the weight and quantity of cables may cause difficulties in task performance by the subject. The universal mobile test bench, equipped with shelves sliding on guide bars (easy admission to medical equipment, configurability) and built-in electric power system, voltage and cooling maintenance system, was used on purpose. This solution limited the number of cables supplying power to the apparatus to only one cable and provided the personnel with convenient placement of apparatus during the simulator's operation. Moreover, employment of modern control and measuring equipment based on PC-class computers enabled remote control of starting and running the apparatus from the instructor's bench, as well as monitoring of the recorded parameters in real time.

\subsection{Data analysis test bench}

It is employed for registration, back-up, analyzing and presentation of the data recorded during the tests. Beside recording of the value of psychophysiological parameters of the tested military aircraft's operators, this bench is also used for presentation of the results, in the form of recommendations for the constructors of the tested interfaces. This bench is placed in different room from the one of the research engineering simulator. The bench is equipped with relevant periphery for data recording and backup, devices for test results presentation, preparation of the subject to performing tests on simulator, and task performance data.

\section{Computer architecture of the simulator}

\subsection{Computer system of the simulator}

In the referred concept, the notion of computer system refers to the system of two components: computer hardware and software, operating in a 
computer network. The following levels of such a system can be distinguished: computer hardware, operating system (system software), application software. Fully automated computer system operates without human's participation. In the referred concept, computer system is supported by human action through Graphical User Interface - GUI. Computer system of research engineeringsimulator should perform the following functions:

- modeling of spatial movement of military aircraft,

- modeling bard systems operation in normal conditions and the selected failure states,

- control of indicators and signaling devices at the operator's bench,

- reading the indications of flight control instruments of the military aircraft,

- data recording required for further analyses and constructing activities,

- information and data display on indicators required for the military aircraft control, as well as for test and constructing activities,

- visualization of the tested aircraft's environment.

Performance of the following functions is connected with the employment of special hardware and software. The subsequent chapters present both hardware and software architecture of the referred concept of the research engineering simulator.

\subsection{Computer system's operation}

There are three phases of operation of research engineeringsimulator's computer system, first of which prepares fundamental data for starting the subsequent one. The phases are:

- preparation of the test/exercise;

- conducting the test experiment;

- analysis of the recorded parameters.

In each of the phases a human communicates with the simulator's system. This communication runs through GUI or other devices having the capability of various data entry and output (mainly medical devices connected to the computer system). The objective of preparation phase of the test/experiment is to develop data required for conducting test experiment, and to record the data in the proper format (Exercise Scenario, Visualization System Data Base). A device called Test/Excercise Scenerio Editor is used at this stage, and its GUI enables: 
- to prepare and to modify test/exercise scenarios;

- to edit Visualization System Data Base through adding and removing artifacts for the certain exercise/test (e.g. vehicles, target shield etc.)

This phase is conducted off-line. The instructor will act as the system's operator in the preparation of the test/exercise. The GUI hardware and software needs to provide the certain test/exercise scenario with capabilities of: creating, modifying, imaging in the most convenient format and painting.

Moreover, there should be the opportunity of sound signalization in case of some situations. The operator from the GUI level needs to have the access to Test/Exercise Scenario Data Base and Environment Visualization System Data Base. The phase of conducting the test experiment is performed online and makes the most technically complex phase of the operation of the computer research engineering simulator's system. This stage is conducted on the basis of two essential computer benches:

- the subject's computer test bench,

- the instructor's computer test bench.

Data recording takes place on a data analysis computer.

The computer system's operation results mainly from the simulation-related functions of the above listed benches, i.e.:

- Visualization and simulation of the selected elements of the designed or upgraded cockpit of military aircraft's.

- Possibility of connecting the instruments for measuring psychophysiological parameters of the tested operator; operation capability; and possibility of the instruments' integration with the simulator's operating system.

- Enabling connection of real elements of the designed device to the tested cockpit/interface, and enabling their operation.

- Providing the capability of mapping visual and acoustic interference similar to those during real flights.

- Enabling connection of real elements to the simulated military aircraft control path and providing their operation.

- Control of exercise/test operation - starting the test/exercise, modification of the conditions of the simulated task, recording required data on the conducted test, switching the simulator off.

- Observation of the subject's performance in cockpit.

- Phonic communication with the tested person. 
The phase of analyzing of the recorded parameters summarizes the two previous phases. The recorded parameters make a starting point for further analyses and evaluation. Comparing the results of a number of strictly defined test experiments should lead to selecting the best constructional solution, as well as the capability of development of the optimized interface. Graphical interface of the test bench for analyzing recorded parameters, which enables the communication between the instructor and the system, should provide the following functions:

- reading data from the Recorded Parameters Base;

- writing data in the Analysis and Result Base;

- data processing in Analysis and Result Base;

- data presentation in different aspects and configurations;

- printing data.

The input data is data introduced to the system by the instructor through GUI of the bench for analyzing recorded parameters, as well as data read from the Recorded Parameters Base.

\subsection{Software architecture}

The referred functions of the computer system result in dividing the computer system's software into several groups:

- Software for modeling spatial movement of aircraft.

- Software for generating graphical interfaces along with interference imitation during the test and sound signals.

- Data-base software for back-up, appropriate acquisition of information required for test and construction activities.

- Communication software ensuring correct cooperation of software modules, as well as cooperation with peripheries.

Mathematic models from the existing library of programs created for over 20 years at Air Force Institute of Technology will be used for simulating the spatial movement of aircraft and its behavior in selected failure state. The library is composed of source codes in FORTRAN language, and the codes concern dynamics of military aircraft in service of the Air Forces of the Republic of Poland. Due to the fact that the remaining parts of the computer system's software will not be made in FORTRAN, the library of mathematical models should be translated into other language or exported as dynamic link libraries (DLL). Software for generating graphical interfaces along with interference imitation, as well as software for generating sound signals will model control panels of aircraft, sound effects for the subject's 
computer and communication interface for the instructor's computer. To speed up the process creating such interfaces, ready-made tools should be used. Air Force Institute of Technology (AFIT) uses Borland's and National Instruments' software environments - respectively Borland Builder and LabView, for this purpose. Software support of data bases is required for the simulator's computer system. To simplify drawing conclusions from recorded data, the record format should be compatible with the format used in the employed medical devices. As for making an optimal selection of tool software for structuring the computer system, presence of libraries supporting the operation of data bases should be considered.

Communication software, which conditions correct cooperation between software modules, as well as cooperation with peripheries, should provide communication with flight control instruments of military aircraft (fingerstick, throttle, pedals). Visualization system with operational support of the subject's psycho-physiological signals requires the simulator's software to support such data exchange protocols, as RS 232 and RS 422, ARINC 429, IEEE 1553 standards. In case of employment of PC-class computer, there is no problem with supporting the first two protocols. The problem appears in case of protocols ARINC 429 and IEEE 1553. In such a case, it is necessary to employ specialized cards with software for communication with the simulator's application. Programming such a system with high-level languages or even object languages such as $\mathrm{C}++$ may be a difficult or time-taking task. It seems that the optimal solution would be to use the tools, which on one hand will offer the library system which supports structuring possibly all of the system's modules, and on the other hand will be easy to master or have already been mastered by the project's programmers. As mentioned before, Borland's Borland Builder $\mathrm{C}++$ and National Instruments' LabView are the tools, used at AFIT, which may be employed for creating the simulator's software. In this connection, it was assumed that one of the above listed tools will be used for creating the simulator's software. Combination of both products will be possible, as well.

\subsection{Hardware architecture of the computer system}

Computer system of research engineering simulator should be developed on the basis of commercial computer hardware of highest quality 
(professional/office version) available at market. GUIs should be composed of the following hardware elements, in order to fully perform their functions:

- Screen monitors (LCD minimum 19");

- Video card, which along with monitors, enables visualization of graphics in resolution not lower then 1280x1024;

As for operating other peripheries, standard and additional cards connected to the computers and enabling communication with the elements of measurement systems and aircraft's flight control instruments, should be provided. It is possible to use additional cards equipped with:

- USB;

- RS (232 or 422).

Flight control instrument's of aircraft should be functionally compatible with real devices and have precisely described communication protocol, which will enable programming them. Control panel of aircraft will be implemented after employment of LCD touch panels.

Communication between the computers should run through a fast computer network, e.g. Ethernet $100 \mathrm{MB}$. Systems for sound generation with the function of signaling failure situations and other possible situations ion aircraft should by employed.

\section{Summary}

Due to the limited size of the publication, this paper outlines the most essential elements of test benches equipment. The issue of sound system, responsible for emission of simulated sound effects, as well as the issue of air-conditioning and lighting, which significantly impact comfort of conducting the tests. Employing available at market technical solutions, software and hardware for constructing research engineering simulator (fig. 4.1.) significantly facilitates constructional activities. 

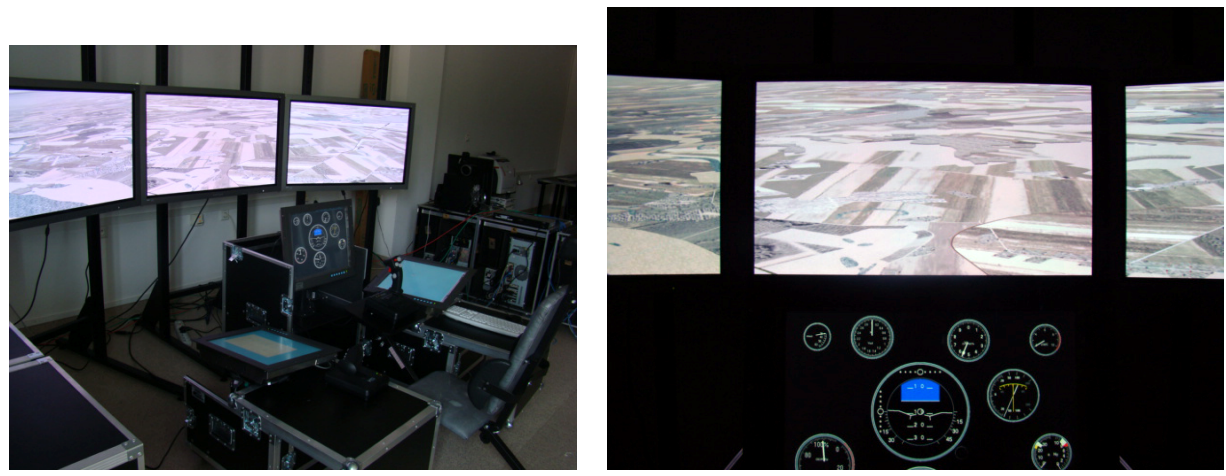

Fig. 4.1. The research engineering simulator.

The referred equipment of test benches (except for medical control and measurement devices) provides quick configuration of the test benches and meeting new requirements or needs related to conducted research work. The test benches' susceptibility to upgrading enables testing and optimization of military airctaft's cockpits of practically all kinds. Adding a subsequent chair for a pilot or an operator of on-board equipment, modification of organization of the flight control instrument board (digital, presented on touch LCD monitors) can be done in short time.

Research work funded from science funding financial means 2006-2008, as for the $R \& D$ project

\section{References}

1. Szczepański C.: Symulatory lotu. Wydawnictwa Politechniki Warszawskiej, Warszawa 1990.

2. Szczepański C. (red.): Analiza i określenie założeń na symulator do badania operatorów wojskowych statków powietrznych. Instytut Techniczny Wojsk Lotniczych 3154/50, Warszawa 2007.

3. Praca zbiorowa: Opracowanie technologii oraz stanowiska do optymalizacji interfejsu czlowiek-maszyna w kokpitach wojskowych statków powietrznych. Projekt wstęny. Instytut Techniczny Wojsk Lotniczych 3171/50, Warszawa 2007. 
4. Butlewski K., Mądrzycki P., Szczepański C.: Koncepcja systemu komputerowego symulatora badawczo-konstrukcyjnego. V Konferencja Awioniki, Rzeszów 2007.

5. Szczepański C.: Koncepcja symulatora badawczo konstrukcyjnego do projektowania kokpitów wojskowych statków powietrznych. V Konferencja Awioniki, Rzeszów 2007.

6. Praca zbiorowa: Opracowanie technologii oraz stanowiska do optymalizacji interfejsu czlowiek-maszyna w kokpitach wojskowych statków powietrznych. Projekt techniczny. Instytut Techniczny Wojsk Lotniczych 3441/50, Warszawa 2007.

7. Praca zbiorowa: Opracowanie technologii oraz stanowiska do optymalizacji interfejsu czlowiek-maszyna w kokpitach wojskowych statków powietrznych. Raport dotyczqcy: Określenia metod wyboru zadania krytycznego dla badanego wojskowego statku powietrznego z punktu widzenia wydolności sterowniczej operatora systemu; Wyboru zadań krytycznych dla samolotu TS-11 „Iskra”. Instytut Techniczny Wojsk Lotniczych 3335/51, Warszawa 2007. 


\section{ZASTOSOWANIE SYMULATORA BADAWCZO- KONSTRUKCYJNEGO W PROCESIE PROJEKTOWANIA I OPTYMALIZACJI INTERFEJSU CZLOWIEK - MASZYNA}

\section{Wstęp}

W procesie optymalizacji interfejsu człowiek - maszyna dla wojskowych statków powietrznych, symulator badawczo-konstrukcyjny jest podstawowym narzędziem badawczym do weryfikacji jakości tego procesu. Zadanie weryfikacji poprawności wprowadzanych rozwiązań konstrukcyjnych interfejsu należy do grupy badań ergonomicznych. W przypadku omawianego symulatora będą one polegały na wykonaniu szeregu pomiarów parametrów psychofizjologicznych operatorów statków powietrznych, korzystających z proponowanych rozwiązań podczas realizacji zadań testowych. W związku $\mathrm{z}$ tym symulator musi umożliwić sprawne przeprowadzenie tych badań, zarejestrowanie i analizę uzyskanych wyników. Zadania i funkcje symulatora badawczo-konstrukcyjnego determinują w istotny sposób rozwiązania konstrukcyjne i warunki otoczenia, w których może on poprawnie funkcjonować i zapewnić wiarygodność prowadzonych badań. Analizę rozwiązań konstrukcyjnych należy więc przeprowadzić w ścisłym powiązaniu z funkcjami i zadaniami realizowanymi przez symulator [1]. Przy takim ujęciu problemu można wyodrębnić stanowiska robocze i określić ich zadania. W skład omawianego symulatora [2] wchodzą struktura informatyczna [3] oraz trzy stanowiska robocze:

- badanego,

- instruktora-badacza,

- analizy danych 


\section{Organizacja i wyposażenie sprzętowe stanowisk badawczych}

\subsection{Organizacja i wyposażenie sprzętowe stanowiska badanego}

Zapewnienie prawidłowego przebiegu badania wymaga od badanego poprawnego wykonania czynności nakazanych przez badacza, a wynikających $\mathrm{z}$ postawionego $\mathrm{w}$ czasie briefingu zadania. Tak więc stanowisko to będzie podstawowym elementem prowadzonych badań. Jego wyposażenie składa się z następujących elementów:

○ Układu prezentacji danych o położeniu statku powietrznego w przestrzeni, jego parametrach lotu i wyposażenia pokładowego (kokpit symulowanego statku powietrznego). Jest on zasilany informacyjnie poprzez komputer stanowiska badanego. W jego skład wchodzą dotykowe monitory ekranowe, panele przełączników symulujących procesy dwustanowe (włączony - wyłączony lub wyboru określonego trybu pracy) oraz stelaż umożliwiający trwałe zamocowanie tych elementów w kokpicie symulatora.

- Organów sterowania położeniem statku powietrznego w przestrzeni.

Organy sterowania badawczego symulatora wojskowego statku powietrznego powinny odwzorować z dużą wiernością rzeczywiste rozwiązania techniczne stosowane w nowoczesnych statkach powietrznych, a przede wszystkim ich funkcje. Rozwiązania problemu można poszukiwać w dwóch kierunkach. Pierwszy to adaptacja kabiny konkretnego wojskowego statku powietrznego wraz ze wszystkimi organami sterowania i tablicą przyrządów pokładowych. Rozwiazzanie to zapewnia wysoki realizm w odwzorowaniu bezpośredniego otoczenia pilota. I jest to jedyna zaleta tego rozwiązania. Wady to przede wszystkim ograniczenie podatności modernizacyjnej kokpitu symulatora badawczo-konstrukcyjnego, który zgodnie z założeniami powinien umożliwić prowadzenie procesu optymalizacji interfejsu człowiekmaszyna dla różnych typów statków powietrznych. Drugi kierunek to zastosowanie gotowych urządzeń imitujących organy sterowania statku powietrznego. Oferta rynkowa gotowych urządzeń jest szeroka, natomiast decyzja o wyborze konkretnego modelu jest uzależniona od dostępności oprogramowania wspierającego użytkowanie urządzeń i jego podatności na zmiany, pod kątem funkcjonowania w symulatorze. Wstępnie do testów, w ramach badań modelu symulatora, wytypowano manipulatory:

- joystick, odwzorowujący sidestick samolotu F-16;

- dźwignia sterowania ciągiem silnika;

- pedały lotnicze. 
- Fotela lotniczego i stelaży do zamocowania organów sterowania i wyposażenia stanowiska prezentacji;

Kierunki rozwiązania problemu są analogiczne, jak w przypadku wyboru rodzaju organów sterowania. Zastosowanie typowego fotela lotniczego z konkretnego typu statku powietrznego narzuca konkretne rozwiązania techniczne i organizacyjne kokpitu oraz generuje dodatkowe koszty. Natomiast symulator $\mathrm{w}$ swoim podstawowym założeniu konstrukcyjnym powinien być urządzeniem uniwersalnym, podatnym na zmiany wyposażenia $\mathrm{i}$ organizacji funkcjonalnej kokpitu. Jako rozwiązanie wyjściowe przyjęto zastosowanie uniwersalnego fotela $\mathrm{z}$ regulacją kątów położenia oparcia, podłokietników oraz odległości platformy podparcia stóp, na której umieszczone będą pedały lotnicze. Zastosowanie tego fotela umożliwi indywidualne dopasowanie pozycji pracy w kabinie symulatora dla każdego badanego. Ponadto konstrukcja stelaża, na którym jest mocowany fotel, umożliwia dołączanie do niego dodatkowych wsporników i półek, które zapewniają dużą podatność rekonfiguracji otoczenia badanego.

- Systemu wizualizacji otoczenia;

System wizualizacji otoczenia składa się z dwóch podstawowych elementów: generatora obrazu oraz układu prezentacji obrazu [4].Wybór układu prezentacji w ostatnim etapie rozważań jego konstrukcji sprowadził się do akceptacji opcji z zastosowaniem ekranów plazmowych, które zapewniają wysoką jakość obrazu. Z przeprowadzonej analizy rozwiązań technicznych wynika, że do systemu projekcji można zastosować bezszwowe monitory plazmowe lub klasyczne, panoramiczne monitory plazmowe z plastikową ramą, które tworzą przerwy w generowanym obrazie. W obu przypadkach brane były pod uwagę monitory o przekątnej ekranu 60 cali.

Montaż monitorów plazmowych odbywa się na specjalnych stelażach, które umożliwiają tworzenie ścian projekcyjnych o różnym kształcie.

\subsection{Organizacja $i$ wyposażenie sprzętowe stanowiska instruktora-badacza}

Stanowisko instruktora-badacza powinno zapewnić realizację następujących funkcji:

- uruchomienie i wyłączenie symulatora oraz zapewnienie ciagłego nadzoru nad jego działaniem;

- modyfikacja warunków symulowanego zadania;

- zapis wymaganych informacji o przeprowadzonym badaniu; 
- możliwość obserwacji działania badanego w kokpicie;

- opracowywanie nowych scenariuszy badań;

- modyfikowanie bazy danych systemu wizualizacji symulatora;

- komunikacja ze stanowiskiem badanego.

Analiza powyższych funkcji symulatora umożliwia określenie jego organizacji i lokalizację w laboratorium oraz technicznego wyposażenia, na które składają się:

○ System komunikacji wewnętrznej pomiędzy stanowiskami badacza i badanego;

- Stanowisko komputerowe instruktora-badacza;

Podstawowe funkcje związane z przygotowaniem i uruchomieniem procesu badawczego będą realizowane za pomocą komputera. Jego klasa, konfiguracja oraz rodzaj oprogramowania użytkowego zostały omówione w [3].

\subsection{System rejestracji parametrów psychofizjologicznych}

Z punktu widzenia prowadzonych badań jest to kluczowy element wyposażenia symulatora. Ze względu na fakt mocowania czujników na ciele badanego oraz niektórych elementów w pobliżu jego fotela, można uznać je za część stanowiska badanego. $\mathrm{W}$ istocie system ten jest wysoce autonomiczny.

Ponieważ podstawowe wyposażenie systemu stanowi aparatura medyczna przeznaczona do pomiaru i rejestracji określonych parametrów psychofizjologicznych badanego, jego elementy powinny być zlokalizowane w pobliżu stanowiska badanego, tak aby sondy i czujniki pomiarowe rozmieszczone na ciele badanego nie wymagały stosowania długich kabli. Ich ciężar i znacząca ilość mogą utrudniać wykonywanie zadań badanemu. Celowym było zastosowanie uniwersalnego, mobilnego stanowiska laboratoryjnego, wyposażonego w przesuwane na szynach półki (łatwy dostęp do aparatury, możliwość szybkiej zmiany konfiguracji wyposażenia medycznego) i dysponującego wbudowanym systemem zasilania elektrycznego, podtrzymywania napięcia i chłodzenia aparatury. Rozwiązanie to ograniczyło liczbę doprowadzanych kabli zasilających aparatury do jednego wspólnego kabla zasilającego oraz zapewniło dogodne dla personelu ustawienie aparatury w czasie pracy symulatora. Ponadto zastosowanie nowoczesnej aparatury kontrolno-pomiarowej opartej na komputerach klasy PC umożliwiło zdalne uruchamianie i sterowanie tą aparaturą ze stanowiska badacza oraz monitoring rejestrowanych parametrów w czasie rzeczywistym. 


\subsection{Stanowisko analizy danych}

Służy ono do rejestracji, archiwizacji, analizy i prezentacji danych zapisanych podczas badań. Oprócz zapisu wartości parametrów psychofizjologicznych badanych operatorów wojskowych statków powietrznych, odbywa się tu także prezentacja wyników w postaci wniosków dla konstruktorów badanych interfejsów. Stanowisko to umieszczone jest w osobnym pomieszczeniu $\mathrm{w}$ stosunku do symulatora badawczego. Jego wyposażenie to komputer wyposażony $\mathrm{w}$ odpowiednie peryferia do zapisu $\mathrm{i}$ archiwizacji danych, urządzenia do prezentacji wyników badan, prowadzenia przygotowania badanych do wykonania prób na symulatorze oraz analizy wykonania zadań przez badanych.

\section{Struktura informatyczna symulatora}

\subsection{System komputerowy symulatora}

W opisywanej koncepcji poprzez pojecie system komputerowy należy rozumieć układ współdziałania dwóch składowych: sprzętu komputerowego oraz oprogramowania, działających również w ramach sieci komputerowej. Można mówić o następujących poziomach takiego systemu: sprzęt komputerowy, system operacyjny (oprogramowanie systemowe), oprogramowanie użytkowe (aplikacje). W pełni zautomatyzowany system komputerowy działa bez udziału człowieka. W opisywanej koncepcji system komputerowy jest wspierany działaniami człowieka poprzez Graficzne Interfejsy Użytkownika (ang.: Graphical User Interface - GUI).

System komputerowy symulatora badawczo konstrukcyjnego powinien, realizować następujące funkcje:

- modelowanie ruchu przestrzennego wojskowego statku powietrznego,

- modelowanie pracy systemów pokładowych w stanach normalnych i wybranych stanach awaryjnych,

- sterowanie wskaźnikami i sygnalizatorami na stanowisku operatora,

- odczytywanie stanu organów sterowania,

- rejestrowanie danych niezbędnych do dalszych analiz i prac,

- prezentowanie na wskaźnikach informacji i danych niezbędnych do sterowania wojskowym statkiem powietrznym oraz prowadzenia prac badawczych i konstrukcyjnych,

- wizualizowanie otoczenia badanego wojskowego statku powietrznego. 
Realizacja ww. funkcji wiąże się z zastosowaniem specjalistycznego sprzętu i oprogramowania. Poniższe rozdziały przybliżą zarówno strukturę sprzętową jak również programową opisywanej koncepcji symulatora badawczo konstrukcyjnego.

\subsection{Praca systemu komputerowego}

Należy wyróżnić trzy fazy pracy systemu komputerowego symulatora badawczo-konstrukcyjnego, z których poprzednia przygotowuje dane stanowiące podstawę do realizacji następnej. Są to:

- przygotowanie badania/ćwiczenia;

- realizacja eksperymentu badawczego;

- analiza zarejestrowanych parametrów.

W każdej z powyższych faz następuje komunikacja człowieka z systemem symulatora. Jest ona realizowana za pośrednictwem GUI lub innych urządzeń umożliwiających wprowadzanie i wyprowadzanie danych w różnej postaci (odnosi się to głównie do urządzeń medycznych przyłączanych do systemu komputerowego).

Celem fazy przygotowania badania/ćwiczenia jest opracowanie niezbędnych dla przeprowadzenia eksperymentu badawczego danych oraz zapisanie ich w odpowiedniej postaci (Scenariusz ćwiczenia, Baza Danych systemu wizualizacji). Na tym etapie wykorzystywane jest narzędzie zwane Edytorem scenariuszy badań/ćwiczeń, którego GUI pozwala:

- przygotowywać i modyfikować scenariusze badań/ćwiczeń;

- dokonywać edycji bazy danych systemu wizualizacji w zakresie dodawania i usuwania dla konkretnego ćwiczenia/badania artefaktów (np.: pojazdów, tarcz strzelniczych i innych).

Faza ta jest realizowana Off-Line. Operatorem systemu w trakcie przygotowania badania/ćwiczenia będzie Instruktor/Badacz. Sprzęt i oprogramowanie GUI w odniesieniu do scenariusza badania/ćwiczenia musi umożliwić jego: tworzenie, modyfikację, zobrazowanie w najdogodniejszej postaci oraz wydruk.

Ponadto powinna istnieć możliwość sygnalizacji dźwiękowej niektórych zdarzeń. Operator z poziomu swojego GUI musi mieć możliwość dostępu do Bazy scenariuszy badan/ćwiczeń oraz Bazy danych systemu wizualizacji otoczenia.

Faza realizacji eksperymentu badawczego odbywa się On-Line i jest najbardziej złożoną technicznie fazą w pracy systemu komputerowego symula- 
tora badawczo-konstrukcyjnego. Ten etap pracy jest realizowany w oparciu o dwa zasadnicze stanowiska komputerowe:

- Komputerowe stanowisko Badanego.

- Komputerowe stanowisko Badacza/Instruktora.

Zapis wyników odbywa się na komputerze analizy danych.

Praca systemu komputerowego wynika głównie z funkcji jakie muszą spełnić w symulatorze $w$ tej fazie ww. stanowiska tj:

- Zobrazowanie i symulowanie działania wybranych elementów kokpitu projektowanego lub modernizowanego statku powietrznego.

- Możliwość podłączenia i pracy aparatury do pomiaru parametrów psychofizjologicznych badanego operatora oraz zintegrowania jej z systemem operacyjnym symulatora.

- Umożliwienie podłączenia i pracy do badanego kokpitu/interfejsu rzeczywistych elementów projektowanego urządzenia.

- Zapewnie możliwości odwzorowania zakłóceń wzrokowych i dźwiękowych zbliżonych do działających podczas rzeczywistych lotów, w czasie prowadzonych badań symulacyjnych.

- Umożliwienie podłączenia i pracy do toru sterowania symulowanym wojskowym statkiem powietrznym rzeczywistych elementów:

- Sterowanie przebiegiem ćwiczenia/badania - rozpoczęcie ćwiczenia/badania, modyfikacja warunków symulowanego zadania, zapis wymaganych informacji o przeprowadzonym badanu, wyłączenie symulatora.

- Obserwacja działania badanego w kokpicie.

- Łączność foniczna z badanym.

Faza analizy zarejestrowanych parametrów jest podsumowaniem dwóch poprzednich faz. Zarejestrowane parametry stanowią punkt wyjściowy dla ich analizy i oceny. Porównanie oceny wyników z realizacji pewnej liczby ściśle określonych eksperymentów badawczych powinno doprowadzić do wskazania najlepszego rozwiązania konstrukcyjnego, jak również umożliwić opracowanie optymalnego interfejsu. Graficzny Interfejs stanowiska analizy zarejestrowanych parametrów, za pośrednictwem którego Badacz będzie się komunikował z systemem powinien umożliwić realizację następujących funkcji:

- odczyt danych z Bazy rejestrowanych parametrów;

- zapisanie danych w Bazie analiz i wyników;

- obróbkę danych w Bazie analiz i wyników; 
- prezentację danych w różnych aspektach i układach;

- wydruk danych.

Danymi wejściowymi są dane wprowadzane do systemu przez Badacza/Instruktora za pośrednictwem GUI stanowiska analizy zarejestrowanych parametrów oraz dane odczytywane z Bazy rejestrowanych parametrów.

\subsection{Struktura programowa}

Z przedstawionych funkcji systemu komputerowego wynika podział oprogramowania systemu komputerowego na kilka grup:

- Oprogramowanie realizujące funkcję modelowania ruchu przestrzennego statku powietrznego.

- Oprogramowanie generujące interfejsy graficzne wraz z imitacją zakłóceń w czasie badania jak również efekty dźwiękowe.

- Oprogramowanie bazodanowe umożliwiające archiwizację, odpowiednią akwizycję informacji niezbędnych do prowadzenia prac badawczych i konstrukcyjnych.

- Oprogramowanie komunikacyjne zabezpieczające prawidłowe współdziałanie modułów programowych jak również współpracę z urządzeniami zewnętrznymi.

Do symulacji ruchu przestrzennego statku powietrznego oraz jego zachowania w wybranych stanach awaryjnych będą wykorzystane modele matematyczne z istniejącej biblioteki programów tworzonych od przeszło 20 lat w ITWL. Bibliotekę stanowią kody źródłowe w języku FORTRAN i dotyczą dynamiki wojskowych statków powietrznych eksploatowanych w Siłach Powietrznych RP. Ze względu na to, że pozostałe części oprogramowania systemu komputerowego symulatora nie będą tworzone w FORTRAN-ie biblioteka modeli matematycznych powinna być przetłumaczona na inny język lub wyeksportowana w postaci bibliotek dynamicznych DLL.

Oprogramowania generujące interfejsy graficzne wraz z imitacją zakłóceń jak również oprogramowanie generujące efekty dźwiękowe, będzie modelowało pulpity sterujące statku powietrznego, efekty dźwiękowe dla komputera badanego oraz interfejs komunikacyjny dla komputera badacza/instruktora. Do tworzenia takich interfejsów należy wykorzystać gotowe narzędzia, które przyspieszą jego tworzenie. Do tych celów w ITWL wykorzystuje się środowiska programistyczne Borland Builder oraz LabView firmy National Instruments. W systemie komputerowym symulatora niezbędna jest programowa obsługa baz danych. Dla ułatwienia wyciągania wniosków z zapisanych danych, format zapisu powinien być zgodny $\mathrm{z}$ for- 
matem przyjętym i stosowanym $\mathrm{w}$ zastosowanych urządzeniach medycznych. Dla dokonania optymalnego wyboru oprogramowania narzędziowego do budowy systemu komputerowego, należy wziąć pod uwagę obecność $\mathrm{w}$ nim bibliotek wspomagających obsługę baz danych. Oprogramowanie komunikacyjne zabezpieczające prawidłowe współdziałanie modułów programowych jak również współpracę z urządzeniami zewnętrznymi powinno zapewnić komunikację $\mathrm{z}$ organami sterowania wojskowym statkiem powietrznym (joystick, przepustnica, pedały). System wizualizacji wraz z obsługą sygnałów psychofizjologicznych badanego narzuca na oprogramowanie symulatora wymóg obsługi takich protokołów wymiany danych jak standardy RS 232 i RS 422, ARINC 429, IEEE 1553. W przypadku sprzętowej realizacji na komputerze klasy PC obsługa pierwszych dwóch protokołów nie stanowi problemu. Pojawia się on dopiero w przypadku protokołów ARINC 429 i IEEE 1553. Wymagane jest wówczas wykorzystanie odpowiednich specjalizowanych kart wraz $\mathrm{z}$ oprogramowaniem, służącym do komunikacji karty z aplikacją symulatora.

Oprogramowanie takiego systemu za pomocą języków wysokiego poziomu czy nawet języków obiektowych typu $\mathrm{C}++$ może okazać się zadaniem trudnym bądź żmudnym do wykonania. Wydaje się iż optymalnym rozwiązaniem będzie wykorzystanie narzędzi, które z jednej strony zaoferują taki zestaw bibliotek, które będą wspomagać budowę możliwie wszystkich modułów sytemu, z drugiej strony będą łatwe do opanowania lub wręcz znane programistom uczestniczącym $\mathrm{w}$ projekcie. Jak wspomniano wcześniej do narzędzi, które są wykorzystywane w ITWL a które mogą posłużyć do stworzenia oprogramowania symulatora są Borland Builder C++ firmy Borland i LabView firmy National Instruments.

\subsection{Struktura sprzętowa systemu komputerowego}

System komputerowy symulatora badawczo konstrukcyjnego powinien być opracowany w oparciu o komercyjny sprzęt komputerowy najwyższej jakości (w wersji biurowej) dostępny na rynku. Aby w możliwie najpełniejszy sposób wypełniać swoje funkcje Graficzne Interfejsy Użytkownika powinny zawierać następujące elementy sprzętowe:

- Monitory ekranowe (LCD minimum 19") ; 
- Karty graficzne, które wraz z monitorami umożliwią zobrazowanie grafiki w rozdzielczości nie mniejszej niż 1280x1024;

W celu obsługi innych urządzeń zewnętrznych należy przewidzieć standardowe i dodatkowe karty podłączone do komputerów umożliwiające komunikację z elementami układów pomiarowych i organów sterowania statkiem powietrznym. Mogą to być dodatkowe karty zawierające urządzenia:

- USB;

- RS (232 lub 422).

Organy sterowania statkiem powietrznym powinny odpowiadać funkcjonalnie urządzeniom rzeczywistym i mieć dokładnie opisany protokół komunikacji z komputerem, który umożliwi ich oprogramowanie. Pulpit sterujący statku powietrznego będzie zaimplementowany przy wykorzystaniu paneli dotykowych LCD. Komunikacja pomiędzy komputerami powinna być realizowana za pośrednictwem szybkiej sieci komputerowej np. Ethernet 100 MB. Powinny być także zastosowane układy generacji dźwięku, realizujące funkcję sygnalizacji sytuacji awaryjnych i innych występujących w kabinie statku powietrznego.

\section{Podsumowanie}

Z uwagi na ograniczoną objętość materiału do publikacji, w artykule zostały omówione najbardziej istotnie elementy wyposażenia stanowisk badawczych. Pominięto system nagłośnienia, odpowiedzialny za emisję symulowanych efektów dźwiękowych oraz systemy klimatyzacji i oświetlenia, które w istotny sposób wpływają na komfort w czasie prowadzenia badań. Zastosowanie dostępnych na rynku rozwiązań technicznych, oprogramowania i wyposażenia do budowy symulatora badawczo-konstrukcyjnego (rys. 4.1) w istotny sposób ułatwia prace konstruktorskie.
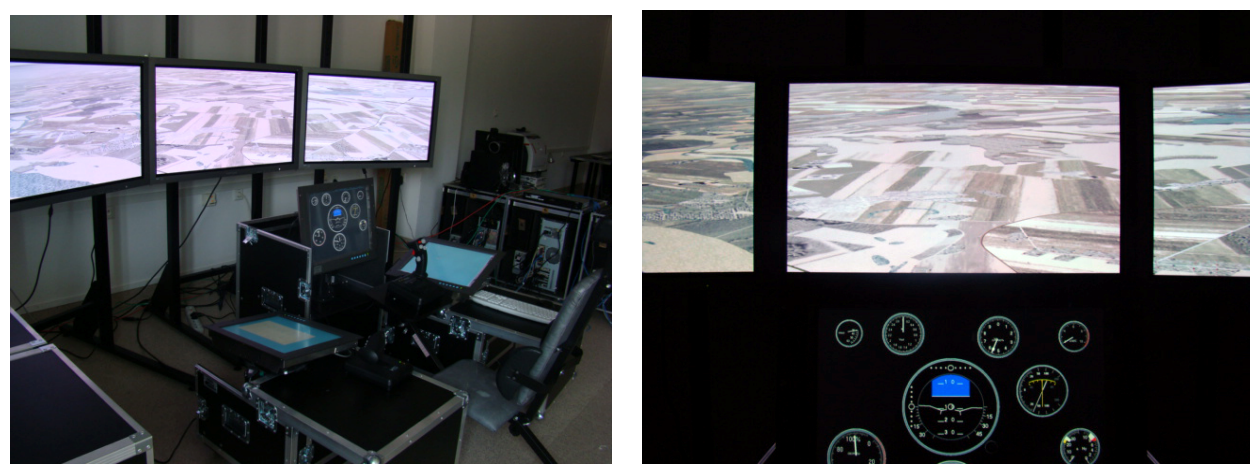

Rys. 4.1. Symulator badawczo-konstrukcyjny 
Opisane powyżej wyposażenie stanowisk badawczych (poza medyczną aparaturą kontrolno-pomiarowa) zapewnia szybką konfigurację stanowisk oraz ich dostosowanie do nowych wymagań lub potrzeb związanych z prowadzonymi badaniami. Podatność modernizacyjna stanowisk badawczych umożliwia badanie i optymalizację kokpitów wojskowych statków powietrznych praktycznie dowolnego typu. Dostawienia kolejnego fotela pilota lub operatora wyposażenia pokładowego, zmiana organizacji tablicy przyrządów pokładowych (cyfrowe, prezentowane na dotykowych monitorach LCD) może być zrealizowane w krótkim czasie.

Praca naukowa finansowana ze środków na naukę w latach 2006-2008, jako projekt badawczo-rozwojowy 